\title{
ON THE ASYMMETRY OF A MERCURY BREAK.
}

\author{
By James Edmund Ives.
}

T $\mathrm{N}$ a paper, now in the course of publication, in the Philosophical Magazine, I have described a peculiar property of a mercury break. While making some experiments to determine the law governing the capacity of the shunted condenser necessary to stop the sparking at the break of an inductive circuit, I discovered that it depends upon the direction in which the current is flowing through the break. The arrangement of the experiment is shown

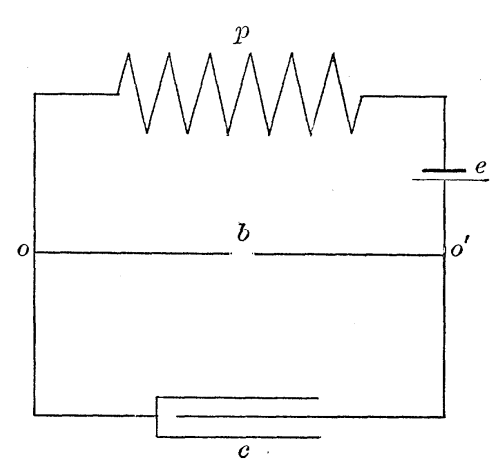

Fig. 1. diagrammatically in Fig. I, where $p$ is a solenoid; $e$, a battery of one or more storage cells; $b$, a mercury break, and $c$, a shunted condenser. It will be noticed that the circuit consists of three branches: opeo', containing the solenoid and the battery; $o b o^{\prime}$, containing the break, and $o c o^{\prime}$, containing the condenser. The break, itself, was an amalgamated copper wire, a millimeter in

diameter, dipped by hand in and out of a small test-tube containing mercury. The test-tube was about two centimeters in diameter, and the mercury was covered with water to a depth of two or three centimeters. The least amount of capacity which must be inserted in shunt around the break to reduce the spark from a large to a small one, has been called, when the solenoid is the primary of an induction coil, the optimum capacity, and will be referred to by this name.

This dependence of the optimum capacity on the direction of the current is such a remarkable fact that I have undertaken some 
further experiments to confirm it, and if possible to determine the cause of it. In the paper referred to, only one experiment dealing with this property of a mercury break is described, and the

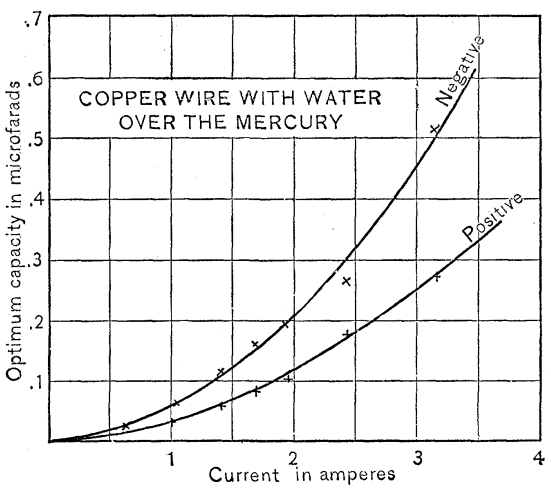

Fig. 2. constants of the branched circuit are not given. Eight new experiments have been made and the results of three of these, typical of all, are given in Table I.

The relation between the optimum capacity and the current, when the breaking pole is an amalgamated copper wire and the mercury is covered with water, is shown by the curves of Fig. 2, plotted from the results of Experiment I, Table I. In these curves the asymmetrical behavior of the current is shown very clearly, the optimum capacity being much greater when the breaking pole is

TABLE I.

\begin{tabular}{|c|c|c|c|c|c|c|c|c|}
\hline \multicolumn{3}{|c|}{$\begin{array}{l}\text { Experiment } \mathrm{r} . \\
\text { Amalgamated Copper Wire. } \\
\text { Water over the Mercury. }\end{array}$} & \multicolumn{3}{|c|}{$\begin{array}{c}\text { Experiment } 2 . \\
\text { Amalgamated Copper Wire. } \\
\text { No Water } \\
\text { over the Mercury. }\end{array}$} & \multicolumn{3}{|c|}{$\begin{array}{l}\text { Experiment } 3 . \\
\text { Iron Wire. No Water } \\
\text { over the Mercury. }\end{array}$} \\
\hline \multirow{2}{*}{$\begin{array}{c}\text { Current } \\
\text { in } \\
\text { Amperes. }\end{array}$} & \multicolumn{2}{|c|}{$\begin{array}{l}\text { Optimum Capacity } \\
\text { in Microfarads. }\end{array}$} & \multirow{2}{*}{$\begin{array}{c}\text { Current } \\
\text { in } \\
\text { Amperes. }\end{array}$} & \multicolumn{2}{|c|}{$\begin{array}{l}\text { Optimum Capacity } \\
\text { in Microfarads. }\end{array}$} & \multirow{2}{*}{$\begin{array}{c}\text { Current } \\
\text { in } \\
\text { Amperes. }\end{array}$} & \multicolumn{2}{|c|}{$\begin{array}{l}\text { Optimum Capacity } \\
\text { in Microfarads. }\end{array}$} \\
\hline & $\begin{array}{c}\text { Breaking } \\
\text { Pole } \\
\text { Positive. }\end{array}$ & $\begin{array}{c}\text { Breaking } \\
\text { Pole } \\
\text { Negative. }\end{array}$ & & $\mid \begin{array}{c}\text { Breaking } \\
\text { Pole } \\
\text { Positive. }\end{array}$ & $\begin{array}{c}\text { Breaking } \\
\text { Pole } \\
\text { Negative. }\end{array}$ & & $\begin{array}{c}\text { Breaking } \\
\text { Pole } \\
\text { Positive. }\end{array}$ & $\begin{array}{c}\text { Breaking } \\
\text { Pole } \\
\text { Negative. }\end{array}$ \\
\hline .63 & .018 & & .80 & .0 & .06 & .7 & .018 & .038 \\
\hline .55 & & .020 & 1.00 & .060 & .09 & .8 & .024 & .047 \\
\hline 1.03 & .033 & .065 & 1.39 & .105 & .16 & 1.0 & .035 & .082 \\
\hline 1.40 & .060 & . 119 & 1.73 & . 155 & .250 & 1.5 & .070 & .159 \\
\hline 1.69 & .084 & .159 & 1.95 & 195 & .326 & 1.90 & . 1117 & .246 \\
\hline 1.94 & .104 & 194 & 2.36 & .261 & .456 & 2.15 & .134 & .261 \\
\hline 2.4 & .177 & .265 & 3.13 & .412 & .801 & & & \\
\hline 3.15 & .274 & .515 & & & & & & \\
\hline
\end{tabular}

negative than when it is positive. By the breaking pole " negative" is meant that it is connected to the negative side of the battery $e$. When "positive" it is connected to the positive side of the battery. 
The change in the direction of the current through the break was made by commuting the connections to the battery. In all these experiments the electromotive force of the battery, consisting of two storage cells, was 4.2 volts; the resistances of the branches $o b o^{\prime}$ and $o c o^{\prime}$ were each .I of an ohm. The inductance of the solenoid, used in all the experiments without an iron core, was $.00028 \mathrm{I}$ of a henry. The current was varied by inserting non-inductive resistance in the branch opeo'. The only inductive resistance in the branched circuit was that of the solenoid.

Thinking that this asymmetry might depend in some. way upon the layer of water over the mercury, I made an

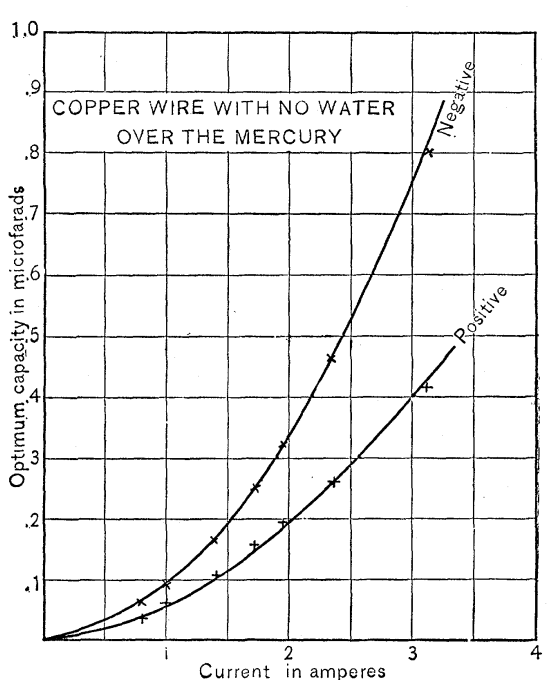

Fig. 3. experiment without any water above it, and obtained the results shown in Experiment 2, Table I., and in Fig. 3.

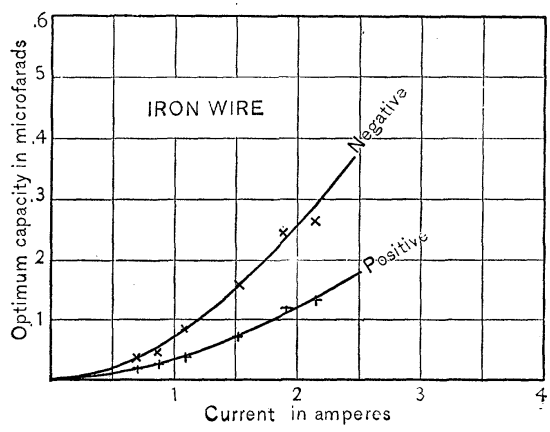

Fig. 4.

It will be seen that the curves are essentially similar to those of Fig. 2. It then seemed that it might be due in some way to the amalgam in the copper wire, and an iron wire .87 of a millimeter in diameter was used instead. The results are given in Experiment 3 Table $I$. and in Fig. 4. The curves are similar to those of Fig. 2and Fig. 3. Since iron does not amalgamate under any circumstances, the effect is not due to the copper amalgam. In the same way a platinum wire was tried, and curves obtained similar to those of Fig. $\dot{4}$. 
My first hypothesis was, that it was due to the fact that in the ordinary mercury break we have a spark passing between a point and a plane, the end of the wire being the point, and the surface of the mercury the plane. To test this, the break was made between an iron wire and a thread of mercury in a capillary tube. The diameter of the iron wire was .o7 of a millimeter, and the diameter of the tube about a millimeter. The results obtained were similar to those of Fig. 4. Since, in this case, the break occurs between two points, and not between a point and a plane the effect is not due to this cause.

In seeking for an explanation it must be remembered that when the circuit $o p e o^{\prime} b o$ is broken at $b$, an oscillatory current is set up in the circuit opeo'co. It seems possible that the asymmetry may be due to some selective action of the mercury vapor generated when the spark passes, of the same nature as the recently discovered Cooper-Hewitt effect. Or it may possibly be due to some capacity effect, such as is found in the Wehnelt interrupter.

I take pleasure in acknowledging the assistance rendered me in these experiments by Mr. Gordon Farnham, of the University of Cincinnati.

Physical Laboratory, University of Cincinnati, March, 1903 . 